
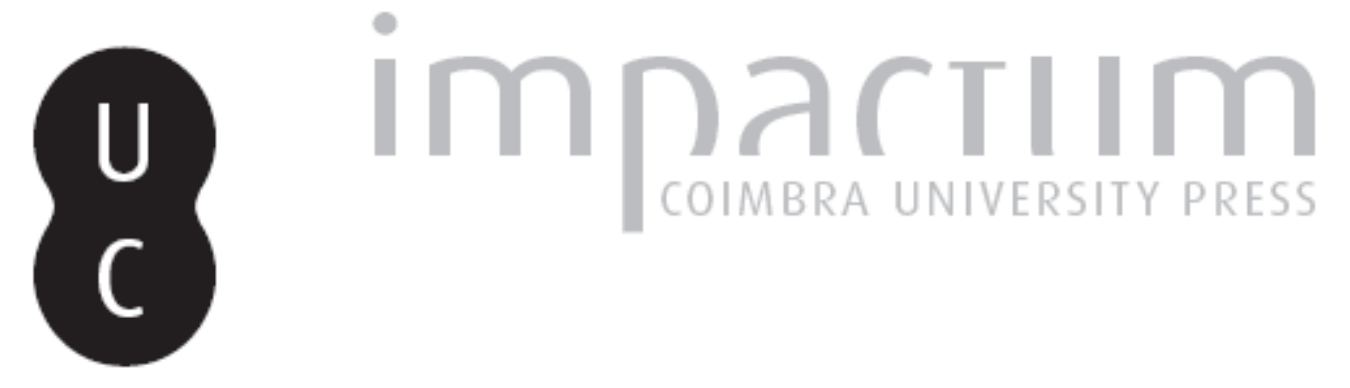

\title{
Ambiguidade, morte e cegueira no Édipo de Séneca
}

\section{Autor(es): Duarte, Ricardo}

Publicado por: Centro de História da Universidade de Lisboa

URL persistente:

URI:http://hdl.handle.net/10316.2/33009

DOI:

DOI:http://dx.doi.org/10.14195/0871-9527_22_11

Accessed : $\quad$ 26-Apr-2023 14:52:51

A navegação consulta e descarregamento dos títulos inseridos nas Bibliotecas Digitais UC Digitalis, UC Pombalina e UC Impactum, pressupõem a aceitação plena e sem reservas dos Termos e Condições de Uso destas Bibliotecas Digitais, disponíveis em https://digitalis.uc.pt/pt-pt/termos.

Conforme exposto nos referidos Termos e Condições de Uso, o descarregamento de títulos de acesso restrito requer uma licença válida de autorização devendo o utilizador aceder ao(s) documento(s) a partir de um endereço de IP da instituição detentora da supramencionada licença.

Ao utilizador é apenas permitido o descarregamento para uso pessoal, pelo que o emprego do(s) título(s) descarregado(s) para outro fim, designadamente comercial, carece de autorização do respetivo autor ou editor da obra.

Na medida em que todas as obras da UC Digitalis se encontram protegidas pelo Código do Direito de Autor e Direitos Conexos e demais legislação aplicável, toda a cópia, parcial ou total, deste documento, nos casos em que é legalmente admitida, deverá conter ou fazer-se acompanhar por este aviso. 

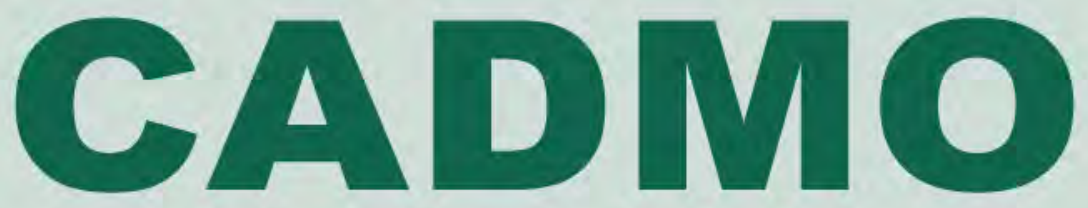

Revista de História Antiga

\author{
Centro de História \\ da Universidade de Lisboa
}

\title{
22
}

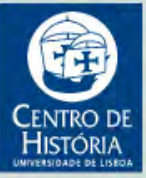

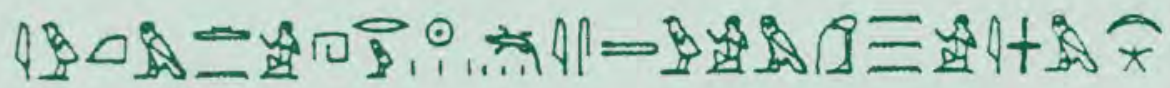

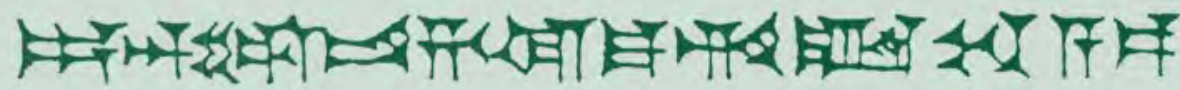
MHNIN AEI $\Delta \mathrm{E} \Theta \mathrm{EA} \Pi \mathrm{\Pi H} \Lambda \mathrm{HIA} \Delta \mathrm{E} \Omega$ 


\section{AMBIGUIDADE, MORTE E CEGUEIRA NO ÉDIPO DE SÉNECA}

RICARDO DUARTE

Universidade de Lisboa

ri_duarte@hotmail.com

ducunt uolentem fata, nolentem trahunt ${ }^{1}$

\section{Resumo}

Da comparação com a obra-prima que é considerado o Édipo Rei de Sófocles, o Édipo de Séneca tende a sair desfavorecido, uma vez que tudo aquilo que aproxima a primeira peça da perfeição parece estar em falta na segunda. Abundam, além disso, as descrições tétricas, pródigas em pormenores lúgubres e sinistros; e as intervenções do Coro, que em Sófocles não constituem fractura na acção, antes a acompanham, são em Séneca, não raras vezes, desligadas, abrindo caminho para reflexões sobre elementos do estoicismo. Um juízo deste tipo, pouco favorável ao Édipo, e à produção dramática do Cordubense em geral, não sobrevive, porém, a uma análise do contexto em que Séneca compôs as suas peças e das diferentes orientações poéticas que o terão guiado, e de que decorreu uma concepção trágica, também ela, diferente. O teatro de Séneca insinua-se como exercício de predicação filosófica. Preceitos essenciais da ética estóica são veiculados por meio de uma forma literária apelativa, capaz de conquistar a atenção de uma audiência alheia às discussões filosóficas e de servir, assim, um marcado intuito moralizante e didáctico-pedagógico. É nosso objectivo ressaltar as principais diferenças no tratamento de um dos mais célebres mitos da Antiguidade Clássica, enquadrando, assim, a composição do Édipo no âmbito do ideário estóico de Séneca.

Palavras-chave: Édipo; estoicismo; paixão; medo; incesto; culpa; morte. 


\section{Abstract}

From the comparison of Seneca's Oedipus to Sophocles' masterpiece Oedipus the King, the former play is usually misjudged, since everything that leads Oedipus the King near perfection seems to be missing in Seneca's play. Oedipus is full of strong emotions, violence, and has also a considerably more violent tone, visible in graphic and gory details. The choral passages, used by Sophocles to comment on the action of the play, to give back story, are often extraneous to the action in Seneca's play and linked to themes and reflections on Stoicism. It's our belief that the analysis of historical and cultural context in which Seneca composed his tragedies, as well as Seneca's drama own orientation, a different one, coming essentially from the fusion of rhetoric and Stoicism, and directed to a didactic aim, discredits the way how scholarly world regards Seneca's Oedipus as a dull and vastly inferior work. Seneca's plays imply an exercise of philosophical predication. Fundamental rules of Stoic ethics are transmitted by a seductive literary form, capable of conquer the attention of a public unaware of philosophical discussions and leading to a moralising purpose. We will be showing the main points of contact and distance between the two plays and contextualizing, in the Stoic vision of the world and the passions, the differences concerning the literary treatment of the legend of Oedipus in Seneca's version.

Key-words: Oedipus; stoicism; passion; fear; incest; guilt; death.

Uma das peças que terá inspirado Séneca na composição do seu Édipo é o Édipo Rei de Sófocles. Séneca apresenta, todavia, uma reconstituição arrojada e inovadora ${ }^{2}$, em que questões que se encontravam no cerne da peça sofocliana - como a procura e a revelação da verdade - são preteridas em favor de tudo o que possa concorrer para um espectáculo intenso e violento: a peça abre com o sentido de culpa por parte de Édipo, o incesto e o parricídio são confirmados nos actos segundo e terceiro, e o diálogo conducente ao reconhecimento das origens de Édipo é confinado ao acto quarto. A acção é praticamente estática e pouco desenvolvida. O suspense dramático do Édipo sofocliano não tem aqui lugar; as odes corais pouco acompanham a acção; e, por fim, se Sófocles retratou um Édipo inteligente, compassivo e com força moral, a quem, com o decorrer da acção, são dadas a ver as falhas morais e emocionais em que incorre, em muito devido aos reveses da mudança de fortuna ${ }^{3}$ sobre os que detêm o poder; Séneca, por sua vez, compõe uma peça em que Édipo tem, logo à partida, um conhecimento intuitivo da culpa que sobre ele impende, e 
a mudança de fortuna que sofre deve-se, antes, ao conhecimento dos factos na origem dessa culpa.

A peça de Sófocles abre com a exibição de um monarca confiante e benquisto, preocupado com os seus súbditos, e em diálogo com as crianças de Tebas e com o sacerdote de Zeus. No auge do seu poder e prosperidade, Édipo simboliza o extremo daquilo que Aristóteles considera «ventura», prestes, todavia, a passar da «prosperidade para a desgraça» ${ }^{4}$.

Por sua vez, no Édipo de Séneca - em que, como acontece em quase todas as suas peças, o prólogo se reveste de especial importância, ao dar o tom e as palavras-chave do drama - é isolado pelo seu próprio poder, e sozinho, que o protagonista se mostra em cena, envolto em dúvida e melancolia, e dominado pela ansiedade ante um fallax bonum (6), o poder real, e sobretudo pelo medo.

lam nocte Titan dubius... Com efeito, as palavras iniciais do Édipo manifestam, desde logo, o tom geral da peça - dúvida, incerteza. Concorrem para esse ambiente diversos factores. Vamos deter-nos sobre a análise de alguns, ao mesmo tempo que procuraremos demonstrar de que forma eles se combinam enquanto móbil da emoção dominante do drama - o medo que assombra Édipo.

Ante o cenário desolador de uma Tebas dilacerada pela peste ${ }^{5}$, Édipo teme; teme pelos seus súbditos, vítimas de voraz morticínio, mas sobretudo por um oráculo ${ }^{6}$ que profetizava o assassínio do pai e núpcias contraídas com a própria mãe. É por recear que esse oráculo fatalmente se cumpra que Édipo abandona Corinto e os seus supostos pais, acabando por «tropeçar» num novo reino (in regnum [incidere ${ }^{7}$ ], 14), Tebas, onde as palavras do deus encontram realização plena.

Édipo enferma, assim, de um affectus, o medo que sente e que o torna incapaz de ver, mesmo quando ainda não se cegou. Procede mal, além disso, pouco ao jeito do sábio estóico, que «não sabe nada acerca de viver na esperança ou no medo» ${ }^{8}$ e para quem «Rei é aquele que pôs de parte o medo" ${ }^{9}$.

Pratt ${ }^{10}$ interpreta inclusive o caos e a instabilidade da condição de Édipo como uma forma de irracionalidade que causa angústia, e em último caso automutilação, e que infecta todo o ambiente envolvente, na medida em que muitas circunstâncias da peça, quase sempre envoltas em ambiguidade, parecem causar ou suportar efeitos derivados do medo - o oráculo de Apolo ${ }^{11}$, a Esfinge, o sacrifício, o extispicium, a história de Actéon $^{12}$, a cena de necromancia ${ }^{13}$, entre outras. 
A peça abre com a referência a um Titan dubius. Titã designa tecnicamente Hiperíon, o Titã pré-olímpico, pai do Sol ${ }^{14}$. Na poesia romana ${ }^{15} \mathrm{e}$ nas tragédias de Séneca, o nome é, no entanto, não raras vezes utilizado para designar Apolo, divindade identificada com o Sol. Assim, o dubius do verso primeiro antecipa já a resposta «dúbia» do oráculo de Febo, transmitido por Creonte.

Ora, os oráculos são, por tradição, ambíguos. A ambiguidade desse oráculo em concreto é reforçada pelas palavras iniciais de Creonte Responsa dubia sorte perplexa latent ${ }^{16}$ (212), dubiam salutem ${ }^{17}(213)$, ambage flexa.../ $\operatorname{arcana}^{18}$ (214-215), dubium.../ ambigua ${ }^{19}(215-216)$-e ressalta das palavras exactas do oráculo, que Séneca dá a conhecer e que associam o poluidor de Tebas ao assassino, predestinado ${ }^{20}$, de Laio, um profugus hospes, «fugitivo hóspede», descrito como incestuoso e que há-legar aos filhos uma guerra fratricida.

$\mathrm{Na}$ transmissão ipsis litteris do oráculo, observa-se a mudança, muito expressiva, de pessoa verbal: da terceira, de tom autoritário, para a segunda, de cariz pessoal, a marcar de forma muito significativa 0 impacto, ainda velado, de cada premonição.

Conclui-se, pois, que a riqueza de informações do oráculo apresentado por Séneca, precisamente por ambíguo e labiríntico, não permite que, a propósito do reconhecimento do assassino, se avance muito mais do que a partir do breve e transparente oráculo do Édipo Rei de Sófocles, que apenas aponta como responsáveis pela peste os assassinos de Laio, que viviam em Tebas (OT, 95-111).

Porque, depois de ouvido o oráculo, a identidade do criminoso é obscura - mesmo para Édipo, o principal visado -, são celebrados dois rituais, sacrifício e observação das entranhas dos animais, ambos presididos por Tirésias, acompanhado pela filha Manto.

Também esses rituais são pródigos em indícios dúbios. São sacrificados dois animais, um touro e uma novilha, que, na opinião da maior parte dos investigadores, representam, respectivamente, Édipo e Jocasta.

Da cena do sacrifício, importa, sobretudo, reter o aspecto variado e mutável da chama, que é comparada a um arco-íris, num passo susceptível de ser interpretado como nova alusão à confusa, incestuosa - e, como tal, dupla - identidade de Édipo, à sua falta de uma única "cara» ou «aspecto» - una facies (315). De uma forma geral, a alternância e mudança de cores aí descritas podem ser entendidas, além disso, primeiro como consentâneas com o relevo concedido à dúvida e à incerteza; e, 
depois - com a referência final a um vermelho sanguíneo -, como alusão, ou ao assassínio de Laio, ou ao suicídio de Jocasta, ou à automutilação de Édipo, ou aos três em conjunto.

O vinho que se transforma em sangue (324) e o fumo que envolve os olhos do rei parecem indiciar a futura cegueira de Édipo. Podem também ser uma sugestão da sua ignorância neste ponto específico da trama ${ }^{21}$.

O «suicídio» da novilha e os ferimentos e a relutância do boi entre a vida e a morte antecipam, respectivamente, o suicídio de Jocasta, e a cegueira e a condição de Édipo no final da peça (mors longa, 949-951).

Por sua vez, a inspecção das vísceras dos animais sacrificados, a fim de delas extrair sinais reveladores do destino - na religião romana, aquilo que se designava por extispicium ${ }^{22}$ - dá a conhecer abominações da natureza (cf. 353-ss.), tais como «um feto da inupta novilha, colocado num lugar estranho e que não é o do costume» (alieno in loco, 373-375). É uma série de fenómenos contra naturam que leva Manto a afirmar, precisamente, «mudada está a ordem, nada jaz no seu lugar próprio» (366) e «a natureza está reversa, nenhuma lei resta no útero» (371).

Trata-se de uma cena da invenção de Séneca e que pouco deve à do diálogo Édipo-Tirésias de Sófocles ${ }^{23}$ (OT, 300-462). Ao invés da cena de tensão e agressividade encenada por Sófocles, e na qual Tirésias identifica Édipo como o assassino de Laio, Séneca cria uma das mais surpreendentes cenas do teatro antigo, envolvendo um sacrifício e um ritual de extispicium, ambos descritos em cena e eventualmente encenados, no palco ou fora dele ${ }^{24}$. Assim, em vez das afirmações directas e com pouco espaço para ambiguidade da cena sofocliana, o público senequiano depara com um espectáculo de pavor e repleto de terríveis indícios. Todavia, esses indícios afigurar-se-iam mais claros para os espectadores do que para as próprias personagens, na medida em que Édipo não é capaz de se reconhecer como o alvo do oráculo ${ }^{25}$, nem Tirésias compreende o sentido das múltiplas sugestões a que os rituais abrem caminho.

Pelo que encerra de simpatia pelos horrores e pela polémica que suscita quanto à possibilidade, ou não, de encenação, esta encontra paralelo na cena de magia da Medeia de Séneca (cf. 670-842).

Resumindo, muitos dos aspectos referidos aquando do sacrifício e subsequente extispicium prefiguram e antecipam eventos posteriore ${ }^{26} \mathrm{da}$ peça: a cegueira de Édipo, o suicídio de Jocasta e, fora já do âmbito desta tragédia em particular, o conflito fratricida entre os filhos de Édipo ${ }^{27}$. 
Outros sinais há que espelham a identidade confusa de Édipo e a sua subversão da natureza.

A par dos indícios que acabámos de referir, é crucial, na peça de Séneca, o paralelo com a Esfinge, no delinear da identidade ambígua de Édipo.

As Esfinges eram monstros lendários, associados sobretudo ao Egipto e por norma descritos como seres alados, com cabeça e peito de mulher, e com corpo de leão. A Esfinge de Tebas aterrorizava os seus habitantes, até ao dia em que Édipo resolveu o célebre enigma. No entanto, ao cometer incesto, ainda que inconscientemente, Édipo cria, ele próprio, novo enigma, mais intrincado. Nas Fenícias de Séneca, 122-124, Édipo refere-se a esse novo enigma, à medida que se vai apercebendo de que ele é um monstro maior, monstrum maius, do que a Esfinge, e de que a substituiu, portanto.

No Édipo de Séneca, a própria sombra de Laio profere palavras que vão no mesmo sentido, ao aludir ao seu assassino como

...um rei cruento, premiado pelo cruel assassínio com o ceptro e que ocupa o tálamo nefando do pai.

[prole odiosa: mas pior como pai do que como filho, de novo um peso no infausto útero] E retornou à sua própria origem e à mãe ímpios descendentes restituiu e, coisa rara até entre as feras, os próprios irmãos ele mesmo gerou - mal intrincado, monstro mais sinuoso do que a sua Esfinge. (634-641)

Outra característica bem definida da identidade de Édipo é a tendência para a opressão. Com efeito, designado por um termo de carga social negativa, rex, Édipo é descrito como uma personagem que desempenha o papel do típico tirano, que mantém a sua hegemonia matando ou livrando-se dos cidadãos mais proeminentes. Provam-no dois diálogos. O primeiro, com Creonte, em que Édipo insiste num dos traços comuns do tirano, tomar o dúbio por certo e exigir a sua destruição - omne quod dubium est cadat (702):

[Creonte] Hei-de, pois, não ouvida a minha causa, cair como culpado? [Édipo] Acaso vos foi dada conta da minha vida? Acaso ouvida foi a minha causa por Tirésias? Porém, pareço-vos culpado. Dais o exemplo: sigo-o.

[Creonte] E se sou inocente?

[Édipo] As coisas dúbias costumam os reis temer ${ }^{28}$ como se fossem reais. 
[Creonte] Quem se atemoriza com medos vãos os verdadeiros merece $^{29}$.

[Édipo] Quem foi acusado, uma vez libertado, sente ódio ${ }^{30}$ : que tudo o que é dúbio pereça. (695-702)

Ironicamente, ao fazer esta imposição, Édipo está a agir, de forma inconsciente e profética, contra si próprio, pois a sua identidade é o expoente máximo do ser dubius. Por sua vez, no segundo diálogo, com o pastor Forbas, Édipo recorre a ameaças de violência e tortura, para obter as informações por que tanto anseia:

[Édipo] A este homem foi por ti entregue outrora um certo menino?

Fala. Hesitas? Porque mudam as tuas faces de cor?

Porque procuras palavras? A verdade odeia demoras ${ }^{31}$.

[Forbas] Revolves coisas encobertas por longo período de tempo.

[Édipo] Confessa, para que te não arranque a verdade, a dor.

[Forbas] A ele como presente inútil dei uma criança:

nem da luz, nem do céu, podia ela fruir ${ }^{32}$.

[Velho Coríntio] Longe vá o agoiro. Ela vive e que viva rogo.

[Édipo] Porque dizes que a criança por ti entregue não resistiu?

[Forbas] Um ferro estreito que atravessava ambos os pés

ligava os membros, o inchaço ${ }^{33}$ nascido da ferida

abrasava o corpo pueril com uma infecção ${ }^{34}$ repugnante.

[Édipo] (Para si próprio) Porque inquires mais além? O destino está próximo.

(Para Forbas) - Quem era essa criança, elucida-me. [Forbas] Proíbe-o a fidelidade.

[Édipo] (Para os guardas) Para cá, alguém, fogo! Já a chama há-de exorcizar a tua fidelidade.

[Forbas] Por tão cruentas vias se inquire a verdade?

Sê clemente, imploro-te. [Édipo] Se feroz te pareço,

e prepotente, tens na mão preparada a vingança:

diz a verdade: quem é ele? Gerado por que pai?

Por que mãe dado à luz? [Forbas] Por tua mulher foi dado à luz. (848-867)

Contraponto de um comportamento, à luz dos preceitos estóicos, maculado por uitium é apontado por Jocasta ${ }^{35}$, que, no acto primeiro, pouco depois de entrar em cena, faz considerações sobre o que é ser rei, sobre as suas responsabilidades, e lembra que Édipo deve permanecer firme e corajoso ante a adversidade e que «não é de homem dar as costas à Fortuna» (86). Ora, as palavras de Jocasta ecoam muitos passos ${ }^{36}$ dos tratados morais de Séneca em que se reflecte precisamente sobre o 
sentido daquilo que deve ser um sábio estóico e, por consequência, um rei ideal ${ }^{37}$. Jocasta apela sobretudo à constantia, marca por excelência do sábio e a que Séneca dedicou o De Constantia sapientis.

Concorre igualmente para o tom de ambiguidade a história do único deus a quem os cidadãos de Tebas se dirigem ao longo de toda a peça: $\mathrm{Baco}^{38}$. A ênfase nas capacidades de metamorfose de Baco e na sua habilidade para alterar - até reverter - o curso da natureza, na ode segunda, vai ao encontro da inversão das leis naturais patenteada no extispicium; e os paradoxos e ambiguidades (masculino/ feminino) da identidade de Baco, patentes no elogio da sua aparência andrógina, feminina (412-428), reflectem, aparentemente, os do próprio rei de Tebas (marido/filho).

Como consequência do tom geral de dúvida e ambiguidade que permeia a peça, dois efeitos sobressaem - o equívoco de nomes e a desordem de relações ${ }^{39}$ a que o incesto abre caminho, aspecto patente sobretudo na parte final e que é manifestado pelos versos 1020-1023:

[Édipo] Poupa já as tuas palavras, mãe, e poupa os meus ouvidos: por estes vestígios do meu corpo mutilado, peço-te, pelo funesto penhor ${ }^{40}$ do meu sangue, por tudo de lícito e ilícito em nosso nome.

Também os versos 1009-1012 e 1034-1036 acentuam essa preocupação com o nomen:

[Jocasta] Como te hei-de chamar?

Filho? Hesitas? Meu filho és: disso tens vergonha;

$[\ldots]$

[Jocasta] Apanhe-se a espada; por causa desse ferro jaz o meu marido - porque o chamas por um nome falso?

Sogro é ele...

Um nome estável é indício de uma identidade igualmente estável, coisa que Édipo julgava ter. No entanto, revelada a verdade, a sua identidade desagrega-se, dada a confusão e pluralidade de nomes levantada pelo incesto: Édipo vê-se no final da peça ante os seus nomina de filho, marido, pai, irmão; Jocasta, ante os de mãe, mulher, avó. Deste modo, se a confiante Jocasta do acto primeiro se dirigia a Édipo por meio do termo coniunx (81), a Jocasta do acto final, por oposição, não sabe por que nome o há-de chamar. 
A preocupação com os nomina e o engano entre eles reflecte, assim, em última instância, a perplexidade perante a confusão existencial motivada pelo incesto.

Depois de levantada a névoa da incerteza e das aparências, Édipo delibera acerca da punição mais adequada a infligir a si próprio. Em Sófocles, não há deliberação, na medida em que a cegueira de Édipo é uma reacção imediata à morte de Jocasta (OT, 1268-1274). Em Séneca, porém, a cegueira de Édipo é completamente independente do suicídio de Jocasta, que é, de resto, posterior. Apesar de poder ser descrita, como em Sófocles, em termos de um acto simbólico de autocastração (cf. 954-957) - e, como tal, uma forma conveniente de punir o incesto -, a cegueira figura, sobretudo, como uma espécie de exílio e, desse modo, como punição mais adequada.

Perante a intensidade da luz da verdade, Édipo escava (cf. eruentis, $\left.961^{41}\right)$, então, os próprios olhos, que qualifica de «maritais» (956-957). Trata-se da única ocorrência do termo maritalis em todo o corpus de Séneca, o que realça a sua grande expressividade. A associação, aqui feita por Édipo, dos olhos às relações sexuais dá força à teoria de Freud de que a cegueira de Édipo seria uma espécie de castração ${ }^{42}$.

A descrição feita por Séneca é mais terrível do que a de Sófocles (OT, 1275-1279), sobretudo porque o Édipo de Séneca não se serve das fíbulas do vestido de Jocasta (OT, 1268-1269; cf. Eur., Pho., 62), mas sim dos próprios dedos, para se cegar. Este foco sobre pormenores sanguinolentos e sobre a violência é típico, não só do teatro de Séneca, mas também de outros autores imperiais, como Lucano ou Estácio.

Em Sófocles (OT, 1263-1264), como em Homero (Od. 11, 278-279), Jocasta enforca-se. Em Séneca, Jocasta mata-se com a espada de Édipo, unindo-se, assim, a Laio, que teria sido morto com essa mesma espada; tornando Édipo num duplo parricida; e, ao ferir-se com a espada no ventre, figurando o acto simbólico de uma união incestuosa tão fatal quanto a união consumada se veio a revelar.

Para os estóicos, o suicídio podia ser entendido como um «acto apropriado ${ }^{43}$, desde que motivado por uma boa razão ${ }^{44}$, isto é, para escapar a condições de vida indignas ${ }^{45}$. Não se sugere, ainda assim, que o suicídio de Jocasta vá ao encontro dos princípios estóicos ou que possa ser visto como um nobre exemplum. Com efeito, é muito significativo reparar em que Jocasta falha em ela própria seguir os conselhos «estóicos» que deu a Édipo, e a que atrás nos referimos. 
Num tratado estritamente estóico, Séneca descreveria, muito provavelmente, um Édipo diferente, tranquilo e presciente, a quem fosse dado ver que há coisas que se encontram sob o domínio do Homem, e outras que não... Todavia, é um Édipo constantemente assolado pelo medo e em luta, na verdade inelutável, contra o destino que Séneca nos apresenta naquela que é classificada por Davis como um «tragédia de destino» ${ }^{46}$, uma tragédia diferente, sim, "estranha» até, na expressão de Gaillard ${ }^{47}$, mas a servir de exemplum a todos os que enfermam das paixões, essas doenças da alma, que matam e cegam.

\section{Notas}

(1) «O destino guia quem o segue, arrasta quem Ihe resiste!» Aforismo de Cícero, traduzido de Cleantes e citado por Séneca na Ep. 107, 11.

(2) Henry et Walker qualificam as diferenças relativas à peça de Sófocles de «extreme» (p. 128).

(3) Aristóteles, Po., 1453a, 15.

(4) Idem, ibidem.

(5) É o próprio Édipo quem, ao abrir a peça, se demora numa descrição dos efeitos devastadores da peste, intimamente ligados às noções de crime e culpa que ocupam a sua mente e que o levam a assumir a responsabilidade pelo infortúnio da cidade - «Tornámos o céu nocivo» (36). A tradução que apresentamos para alguns dos passos citados do Édipo é da nossa autoria (cf. Séneca. Édipo, Lisboa: Artefacto, 2012). A primeira intervenção do Coro segue, muito de perto, o tema do prólogo e complementa até a parte em que são descritos os efeitos nefastos da peste. Enquanto relato da calamidade que sobre Tebas se abate, assoma, portanto, como alargamento do que no prólogo era feito mero intróito. A descrição inicial da peste feita por Édipo é aqui desenvolvida por aqueles que com ela mais sofreram, os próprios Tebanos (124-170 e 180-201). A minuciosa descrição que é feita de uma Tebas gangrenada pela epidemia pode ser entendida como inversão radical da simpatia universal que os estóicos defendiam. Desfeitas as barreiras entre a vida e a morte, já os vivos conviviam com os mortos.

(6) Quer a peste, quer o oráculo, são elementos que constam do Édipo Rei de Sófocles, ainda que isolados em diferentes partes da peça. A antecipação e junção desses dois elementos na peça senequiana terá que ver, muito provavelmente, com o novo perfil psicológico do Édipo aqui desenhado, e que encontra no medo do incesto, por ele considerado o «crime maior» (maius... scelus/maius... nefas, 17-18), um dos seus traços estruturantes. Com efeito, Boyle (2011, Ivii) considera que «this new self-distrusting, fragmented Oedipus is strikingly more Freudian than his Sophoclean predecessor [...]».

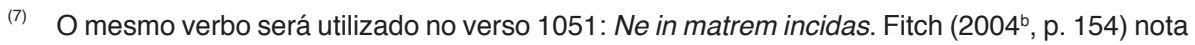
a conotação sexual de in... cadere (Cícero, Cael. 69) e de in incidere (Séneca-o-Retor, Con. 1, $5,2)$. Neste sentido, «tropeçar na mãe», in matrem incidere, foi o maius scelus, «crime maior» (17), de Édipo.

(8) Séneca, Const. 9, 2.

(9) Idem, Thy., 348. 
(10)

Pratt (1963), p. 224.

(11) Como bem viu Boyle (2011, Ivii), o oráculo que Laio teria recebido, a profetizar a sua morte às mãos do próprio filho (Sófocles, OT, 711-714), é omitido na peça de Séneca, em que a atenção se encontra, logo desde início, centrada no oráculo dirigido a Édipo, de que havia de matar o pai e casar com a mãe.

(12) Actéon, transformado em cervo por ter visto Diana banhar-se. Depois de o transformar em cervo, a deusa enfureceu os cinquenta cães que compunham a sua matilha e incitou-os contra ele. A referência ao mito de Actéon neste contexto é muito expressiva e antecipa a acção dramática. Tal como Actéon, também Édipo é um descendente de Cadmo que comete, de forma não intencional, um acto proibido, em consequência do qual é transformado num ser híbrido (irmão para os próprios filhos, filho para a própria mulher). Merece igualmente relevo o facto de Actéon se aperceber da sua monstruosidade ao regressar ao local onde ela teve origem, na medida em que, no acto quarto, Édipo experimenta uma situação idêntica, ao recuar até às suas verdadeiras origens, através do diálogo com o Velho Coríntio e o pastor Forbas.

(13) É Creonte quem faz uma longa descrição deste ritual (trata-se do segundo maior monólogo, ininterrupto, das peças de Séneca, apenas ultrapassado pelo discurso de Euríbates em Ag., 421-578). Depois de descrever o local do ritual (530-547), enumeram-se os preparativos de Tirésias, que incluem o abrir de uma cova e a cremação de animais vivos (548-558). Seguem-se duas invocações formais à morte, assentidas pela terra e pela floresta (559-581). Abre-se a terra, e emergem as sombras e os monstros (582-607), com especial realce para as sombras de conhecidos Tebanos - Zeto, Anfíon, Níobe, Agave, as Bacantes, Penteu e, por fim, Laio. A narrativa termina com o discurso de Laio, em que o rei morto acusa Édipo de parricídio e de incesto, e profetiza uma guerra civil. Laio dá ainda instruções para que Édipo seja expulso da cidade, a fim de libertá-la finalmente da peste. Ao fazê-lo, Laio antecipa aquele que há-de ser o final da peça, já que vaticina a cegueira de Édipo, o seu exílio e a necessidade de recorrer a um bordão.Séneca é, neste passo, tributário das palavras finais do discurso do Tirésias de Sófocles (OT, 452-456), apesar de introduzir uma inovação - Laio enquanto agente da queda de Édipo - e uma nova ironia: «opor grandes demoras» aos pés de Édipo, e retê-lo, foi precisamente o que Laio havia feito aquando do nascimento do filho.

(14) Hesíodo, Th., 371-374.

(15) E.g., Ovídio, Met.

(16) «As respostas jazem dúbias num oráculo sinuoso».

(17) [Oe.] Dubiam salutem qui dat adflictis negat - «Quem uma salvação dúbia apresenta, nega-a aos desesperados».

(18) [Cr.] Ambage flexa Delphico mos est deo / arcana tegere... - «De ambiguidade tem o deus délfico o costume de os seus enredados /mistérios cobrir».

(19) ... [Oe.] Fare, sit dubium licet: / ambigua soli noscere Oedipodae datur. - «Fala, ainda que seja algo dúbio: / as coisas ambíguas só a um Édipo é dado conhecer». Um traço recorrente e característico do teatro senequiano é a autodramatização, por parte das personagens, dos seus próprios nomes e dos mitos a que dão vida (cf., por exemplo, os casos de Hércules, $H F, 1218$; ou de Medeia, Med., 166), o que traduz a intensificação do sentido de teatralidade da própria peça, pondo em evidência uma dimensão metateatral. Édipo é a única personagem da peça que se nomeia a si própria (neste passo e ainda nos versos 943 e 1003). Ironicamente, o nome que mais vezes aparece na peça é o de Laio (7 vezes).

(20) ...Phoebo iam notus et infans, «já conhecido de Febo desde criança» (235). Uma das inovações de Séneca ao tratar o mito de Édipo radica no postular da sua predestinação. A este respeito, veja-se a afirmação do próprio Édipo nos versos 877-878: qua luce primum spiritus hausi 
rudes / iam morte dignus... «desde o dia primeiro em que sorvi o ar ainda não experimentado, / já da morte digno» (877-878).

(21) À luz dos sinais que na Eneida predizem o suicídio de Dido - in obscenum se vertere uina cruorem, "os vinhos que derramara em sangue funesto convertidos» $(4,455)-$, o vinho que se transforma em sangue pode igualmente apontar para o suicídio de Jocasta.

(22) Apesar de ser considerado uma prática de origem pré-romana, e de a inspecção das entranhas das vítimas, por parte dos sacerdotes (haruspices), ser um rito originariamente etrusco, o extispicium veio a ser definitivamente abraçado pelos Romanos. A divinação ou predição do futuro por meio de sinais era, no geral, aceite pelos estóicos, cujas doutrinas acerca do papel do destino no decurso da história e da simpatia universal entre todas as coisas abonavam a sua prática. A este respeito, vejam-se, por exemplo, Posidónio, Cícero (Diu.) e o próprio Séneca (Nat. $2,32,4$ ), para quem «o curso do destino» (fatorum series) «envia para toda a parte, de antemão, sinais do que está para vir» (indicia ubique uenturi praemittens).

(23) Que retrata Tirésias como adivinho, e não como arúspice.

(24) Acerca do que tem sido dito a propósito desta questão, e da opinião de autores como Zwierlein e Töchterle, de que cenas deste tipo atestam a teoria de que as peças de Séneca não seriam passíveis de ser representadas, veja-se, a título de exemplo, Boyle (2011, p. 187).

(25) Assim, ao ser retratado como livre de dúvidas quanto ao seu nascimento e origens, também neste ponto o Édipo de Séneca difere do Édipo de Sófocles.

(26) A este respeito, veja-se Ferreira $\left(2011^{\mathrm{b}}\right)$.

(27) Cf. 321-323, 324-327, 337-339, 341-344, 347-348, 348-350, 359-360 e 363-365

(28) O medo é aqui indicado como um atributo definidor dos poderosos. A sua estreita ligação com figuras tirânicas é o tema central da República de Platão (cf., e.g., 579d-e) e é também tratada por Séneca no De Clementia (1, 7, 3; 13, 1-3 e 19, 5). A libertação do medo, qualquer que fosse a sua origem, era uma das características do sapiens estóico (cf, e.g., Séneca, Const. 9, 2).

(29) Na Ep. 110, 5, Séneca declara que todos os medos são causados por motivos vãos.

(30) O público romano não deixaria de ter presentes algumas ilustrações desta sententia, incluindo o caso de Bruto, assassino do homem que o havia perdoado (César).

(31) Em Ira 2, 22, 3, afirma-se, contrariamente, que a ueritas requere tempus.

(32) Forbas quer dizer que o recém-nascido não poderia viver, mas a forma como se expressa antecipa a condição última de Édipo, que, cego, não poderá, nem da luz, nem do céu, «fruir» (971-973 e 998-1003).

(33) Tumor. O inchaço da ferida havia já sido referido (813). Forbas prepara-se para presenciar o tumor de Édipo num sentido diferente: a ira do tirano. Sobre o tumor enquanto inchaço provocado pela ira, veja-se, e.g., Ira 1, 20, 1 ou Pho., 352.

(34) O uso do termo lues, que atrás designara a peste de Tebas (29), a Esfinge (107) e a abstracção «Peste» (652), a conotar a «infecção» que alastrava pela ferida do recém-nascido não é acidental. Séneca sugere, em termos verbais, que a origem da peste tebana está relacionada com a ferida de Édipo. Acerca do furor de Édipo como derradeiro sintoma da peste, vejam-se os versos 957-961.

(35) Diz Palmieri (p. 125) «Giocasta pronuncia le parole dello stoicismo».

(36) Prou. 2, 1; Prou. 1, 4, 12; Tranq. 4, 1-2; Tranq. 11, 1 e Ep. 13, 1-3.

(37) Isto porque, para os estóicos, o rei ideal e o sábio eram idênticos - cf. Erskine, pp. 73-74. 
(38) Assinala Boyle (2011, Ixiii) que a falha, por parte de Édipo, de não referir uma única vez o nome do deus patrono de Tebas, cuja identidade confusa, como vimos, reflecte a do próprio protagonista, o marca como candidato a sofrer uma transformação similar à de Penteu (442-444) ou Licurgo (471), eles que também desprezaram Baco.

(39) Muitos foram os autores romanos que sublinharam as relações familiares pouco ortodoxas, como o muito famoso caso de Pompeio e Júlio César, gener, genro, e socer, sogro, respectivamente (Vergílio, Aen. 6, 830-831; Lucano 1, 289-290). Este tipo de relações era característico da vida aristocrática romana, em que o casamento era quase sempre móbil de alianças políticas e sociais. Relações pouco convencionais na própria corte imperial (Agripina era sobrinha e mulher de Cláudio, e suposta amante do próprio filho, Nero; Octávia era meia-irmã e mulher de Nero); e histórias como a de Édipo, ou dos deuses do Olimpo (e.g., Juno era irmã de Júpiter), iam contra a norma moral que seria desejável para Roma.

(40) Sanguinis pignus mei. Passo expressivo, cuja ambivalência «matches the confounding of relationships in this family» (Fitch [2004 ${ }^{\mathrm{a}}$ ], p. 109). Pode ver-se aqui uma referência aos laços de sangue de Édipo com a sua mãe (Fitch), ou uma alusão aos amaldiçoados filhos de Édipo e Jocasta. Pignus, «penhor», era aplicado frequentemente a crianças na literatura latina, a designar uma parte do contrato do casamento, enquanto concretização física do vínculo entre duas famílias e da firmeza do amor dos pais.

(41) 957-961: ...Dixit atque ira furit: / ardent minaces igne truculento genae / oculique uix se sedibus retinent suis; / uiolentus audax uultus, iratus ferox / iamiam eruentis...: «...Disse e com ira enfureceu-se: / ardem as ameaçadoras faces com fogo terrível / e os olhos a custo se mantêm nas órbitas; /violenta, audaciosa fisiognomia, irada, feroz, / do que agora se prepara para escavar...».

(42) Freud (1913), 130, n. 1.

(43) Crisipo (Plutarco, Stoic. rep. 1042d).

(44) Cícero, Tusc. 1, 74.

(45) Idem, Fin. 3, 60-61; Séneca, Ira 3, 15, 3-4 e, sobretudo, Ep. 70. O desejo de morte é expresso por muitas das principais figuras das tragédias de Séneca - Jocasta (Oed., 1024-1039); Helena (Tro., 938-944); Políxena (Tro., 945-948); Hécuba (Tro., 1171-1177); Édipo (Pho., 31-50); Electra e Cassandra (Ag., 994-1012). Veja-se ainda Octávia, em Oct., 107-108, 135-136, 961-968, e Hércules, em HO, 1711-1712.

(46) Davis (1991), p. 150. O autor afirma que o conceito de fatum é a tónica dominante do Édipo latino. Traduz essa tónica a repetição da palavra fatum ao longo de toda a peça: contam-se 27 ocorrências (19, 28, 72, 75, 125, 206, 297, 411, 711, 751, 780, 787, 792, 832, 860, 882, 915, 926, 980 [bis], 993, 994, 1019 [bis], 1043, 1046, 1059).

(47) Gaillard (1992), p. 133.

\section{Referências}

\section{TEXTOS}

AHL, Frederick (2008). Two Faces of Oedipus: Sophocle's Oedipus Tyrannus and Seneca's Oedipus, Ithaca, Cornell University Press

BOYLE, Anthony J. (2011). Seneca. Oedipus, Oxford University Press

DUARTE, Ricardo (2012). Séneca. Édipo, Lisboa, Artefacto 
FITCH, John G. (2004ª). Seneca Tragedies: II, Cambridge.

MILLER, Frank J. (1968). Seneca's Tragedies, London, William Heinemann Ltd.

TÖCHTERLE, K. (1994). Lucius Annaeus Seneca Oedipus. Heidelberg.

WATLING, Edward F. (1966). Seneca. Four Tragedies and Octavia, London, Penguin.

ZWIERLEIN, Otto (1986). L. Annaei Senecae Tragoediae, Oxford University Press.

\section{ESTOICISMO}

BRUNSCHWIG, Jacques et NUSSBAUM, Martha (eds.) (1993). Passions \& Perceptions. Studies in Hellenistic philosophy of mind, Proceedings of the Fifth Symposium Hellenisticum, Cambridge.

DURKHEIM, Émile (1986). Le suicide: étude de sociologie, Paris, Presses Universitaires de France (trad. port. Luz Cary, Margarida Garrido, J. Vasconcelos Esteves, O Suicídio. Estudo Sociológico, Lisboa, Editorial Presença, 1982³).

ERSKINE, A. (1990). The Hellenistic Stoa, Ithaca, NY.

GOURINAT, Jean-Baptiste (2007). Le stoïcisme, Paris, Presses Universitaires de France, col. "Que sais-je?», n. ${ }^{\circ} 770$.

INWOOD, Brad (ed.) (2003). The Cambridge Companion to the Stoics, Cambridge.

INWOOD, Brad (ed.) (2005). Reading Seneca, Stoic Philosophy at Rome, Oxford University Press. LAURAND, Valéry (2002). Le vocabulaire des stoïciens, Paris: Ellipses.

MITSIS, Phillip (1993). «Seneca on reason, rules and moral development», Brunschwig \& Nussbaum eds., 285-312.

NUSSBAUM, Martha (1987). «The Stoics on the Extirpation of the Passions», Apeiron 20, 129-177.

NUSSBAUM, Martha (1993). «Poetry and the passions: two Stoic views», Brunschwig \& Nussbaum eds., 97-149.

\section{TEATRO de SÉNECA e ÉDIPO em particular}

ÁLVAREZ MORÁN, María C. (1972). «El Edipo de Séneca y sus precedentes», CFC 7, 181-239.

ARMISEN-MARCHETTI, Mireille (1989). Sapientiae Facies: étude sur les images de Sénèque, Paris, Belles Lettres.

BORGO, Antonella (1998). Lessico Morale di Seneca, Napoli, Loffredo Editore S.P.A.

CAMPOS, José A. S. (1983-1984b). «Para uma interpretação do Oedipus de Séneca: o Prólogo», Euphrosyne 12, 223-232.

CAMPOS, José A. S. (1987). «A linguagem dos gestos no teatro de Séneca», Euphrosyne 15, 109-34.

DAVIS, P. J. (1991). «Fate and human responsability in Seneca's Oedipus», Latomus 50, 150-163.

DUPONT, Florence (1995). Les monstres de Sénèque. Pour une dramaturgie de la tragédie romaine, Paris, Belin. 
FERREIRA, Paulo S. M. (2011ª). Séneca em cena. Enquadramento na tradição dramática greco-latina, Lisboa, FCG-FCT.

FERREIRA, Paulo S. M. (2011 ${ }^{\text {b}}$. "O extispicium no Oedipus de Séneca e a Guernica de Picasso", Mundo \& Letras (vol. 2), SP, José Bonifácio, 75-84.

FITCH, John G. $\left(2004^{b}\right)$. Annaeana Tragica: Notes on the Text of Seneca's Tragedies, Leiden.

FREUD, S. (1900). The Interpretation of Dreams, tr. J. Crick (1999), Oxford.

FREUD, S. (1913). Totem and Taboo, Vol. 13, Standard Edition of the Complete Psychological Works of Sigmund Freud, ed. J. Strachey (1953-1974), London.

FUENTES, María C. G. (2006). «La saga de los Labdácidas y la de los Pelópidas en la tragedia senecana», Cuadernos de Filología Clásica. Estudios Latinos, 26/1, 55-75.

GIANCOTTI, Francesco (1953). Saggio sulle tragedie di Seneca, Roma, Napoli: Città di Castello.

HENRY, D. e WALKER, B. (1983). «The Oedipus of Seneca. An imperial tragedy», Ramus 12, 128-139.

HERRMANN, Léon (1924). Le théâtre de Sénèque, Paris: Les Belles Lettres.

MASTRONARDE, Donald J. (2008). «Seneca's Oedipus: The Drama in the Word», Fitch ed., 221-243.

PALMIERI, N. (1983). «Sulla struttura drammatica dell' Edipo di Seneca», AFLS 4, 115-64.

PARATORE, Ettore (1956). «La poesia nell' Oedipus di Seneca», GIF 9, 97-132.

PIMENTEL, Maria C. C. M. S. (1999). «A meditatio mortis nas tragédias de Séneca», Classica 23.

PRATT, N. T. (1948). "The Stoic base of Senecan drama»: TAPhA 79, 1-11.

PRATT, N. T. (1963). «Major Systems of Figurative Language in Senecan Melodrama», TAPhA 94, $199-234$.

TARRANT, R. J. (1978). «Senecan drama and its antecedents», HSPh 82, 213-263.

TRAINA, A. (1979). «Due note a Seneca tragico», Maia 31, 273-276.

ZWIERLEIN, Otto (1966). Die Rezitationsdramen Senecas, Meisenheim a. Glan.

ZWIERLEIN, Otto (1976). «Versinterpolationen und Korruptelen in den Tragödien Senecas», WJA 2, 181-217. 